How to cite this article:

Al-Ttaffi, L. H. A., Bin-Nashwan, S. A., Amrah, M. R. (2020). The influence of tax knowledge on tax compliance behaviour: A case of Yemeni individual taxpayers. Journal of Business Management and Accounting, 10(2), 15-30.

\title{
The Influence of Tax Knowledge on Tax Compliance Behaviour: A Case of Yemeni Individual Taxpayers
}

\author{
Lutfi Hassen Ali Al-Ttaffi*, Saeed Awadh Bin-Nashwan \& \\ Muneer Rajab Amrah \\ Faculty of Administrative Sciences, Seiyun University, Yemen
}

Received: $3 / 6 / 2020$

Revised: 28/8/2020

Acccepted: 9/9/2020

Published: 15/11/2020

\begin{abstract}
This paper aims to enhance the understanding of tax compliance behaviour of individual Yemeni taxpayers. It investigated the influence of tax knowledge on the behaviour of taxpayers. A survey was used to collect the required data. The major finding of this study is that tax knowledge of citizens has a significant influence on their likely compliance behaviour. Specifically, compliance behaviour increases when tax knowledge is higher. This study is probably among the first to investigate and to provide evidence on the influence of citizens tax knowledge on tax compliance behaviour in Yemen. The outputs of this study could serve as a useful input, not only for tax policy and strategy in Yemen, but also in other developing countries. Thus, governments are recommended to work on increasing tax knowledge of its citizens which will result in improving the level of tax compliance.
\end{abstract}

Keywords: Tax knowledge, tax compliance, Yemen

\subsection{Introduction}

The problem of tax non-compliance is as old as the tax system (Wentworth \& Rickel, 1985). This has always been a problem to tax administrations in most countries.

* Corresponding Author: Tel: 00967700442632 / 00967773637852

E-mail: alttaffilutfi@yahoo.com / lutfialttaffi@gmail.com 
Additionally, it seriously impacts the global economy, therefore it has long been an issue confronting governments throughout the world. As such, there is a large and rich research literature in this field (Ross \& McGee, 2012; Mohdali \& Pope, 2012). All economies in the world, whether developed or emerging, are affected by this phenomenon. However, the level of tax non-compliance in developing countries is much more than developed countries (Umar, Derashid \& Ibrahim, 2017; Mas'ud, Aliyu and Gambo, 2014). Among the Middle Eastern countries, Yemen is categorised as one of the least developing countries suffering from huge financial and administrative problems including non-compliance of tax (Transparency International's Quarterly Newsletter [TIQN], 2016). In 2004, the Self-Assessment System (SAS) was introduced in Yemen to facilitate the process of collecting tax revenue and to reduce delays in disbursing collected revenues to the government. Nevertheless, the amount of tax non-compliance in Yemen is still significant (Aziz \& Al-Harethi, 2018). Therefore, this issue has attracted a lot of scholarly as well as government interest in terms of understanding the phenomenon and possible solutions.

Globally, numerous studies on tax compliance primarily concentrated on the economic perspective and later, to some extent, integrated the social, psychological and legal perspectives as well (Al-Ttaffi \& Abdul-Jabbar, 2018). The lack of empirical research on other aspects can be attributed to the reality that social influences are extremely difficult to identify (Mohdali \& Pope, 2012; Al-Ttaffi \& Abdul-Jabbar, 2018). After reviewing the relevant literature, it seems that the influence of tax knowledge on taxpayer's behaviour has rarely been investigated in the Middle Eastern context, especially Yemen. Tax knowledge, in general, is an understanding of the essential tax policy concepts implemented within a country (Fauziati, Minovia, Muslim \& Nasrah, 2016). An understanding of the tax policies by taxpayers determines their compliance with the tax system. Arguably, tax knowledge is an essential element in a voluntary compliance tax system, particularly in determining accurate tax liabilities (Baru, 2016).

By focusing on Yemen as a developing country, the current study answered the call from many studies on tax non-compliance to bridge the gap between developing and developed countries (Feust \& Riedel, 2009). Additionally, the study provides evidence on the influence of tax knowledge on the likely behaviour of taxpayers. It constitute a contribution to the literature on tax compliance in developing countries and the Middle East in particular. The main objective of the study is to empirically investigate the level of tax knowledge among individual taxpayers in Yemen and also to investigate the influence of tax knowledge on taxpayers' compliance decisions. The study is structured as follows: Section 2 addresses the problem statement of the study. Related literature were reviewed in section 3. The research method, data analysis results and discussion are presented in Section 4 and 5 respectively. Finally, in Section 6, concluding remarks, limitations and future directions are discussed. 


\subsection{Statement of the Problem}

In Yemen, tax non-compliance is a major issue and has reached a very alarming proportion (Ministry of Planning \& International Cooperation [MPIC], 2018). Despite reforms which have been performed to overcome weaknesses in the tax system, statistics show that the amount of tax non-compliance is on an increasing trend and remain a serious concern because it constitute serious financial problem to the government (United Nations Development Program [UNDP], 2005; Central Organization of Control \& Audit [COCA], 2016; MPIC, 2018).

Specifically, during the period from 2004 to 2014, it was discovered that the volume of tax non-compliance increased steadily from USD164 million in 2004 to USD2 billion in 2009. It then increased to USD 2.5 billion in 2012 to USD 3 billion in 2013 and USD 4 billion in 2014 (MPIC, 2009; COCA, 2016). Al-Saadi (2014), who used to be the Minister of Planning and International Cooperation of Yemen, stated that the issue of low collection of tax in the country has led to a serious financial crises. Furthermore, in terms of Gross Domestic Product (GDP), when compared to other countries, it seems that the average tax revenues to GDP of Yemen amounted to only $6.68 \%$.for the period between 2008 and 2013, compared to $14.3 \%$ and $16 \%$ of GDP in countries that have similar economies such as Egypt and Jordan respectively. Other countries such as Morocco, Tunisia and Lebanon collect more than 20\% of their GDPs as tax (World Bank, 2018). Overall, the low contribution of tax revenues in GDP may be largely due to low tax compliance behaviour among Yemeni taxpayers. The low compliance is a result of the fact that tax authorities do not adequately investigate the determinants of taxpayer's non-compliance behaviours (Obaid, Ibrahim \& Udin, 2020).

This study mainly focused on individual taxpayers in Hadhramout, Yemen. After the 2011 revolution and 2015 crisis in Yemen, many factors that may affect tax compliance emerged (Al-Ttaffi, 2017). Exploring the issue of internal values among individual taxpayers is a more reasonable approach because an individual is more likely than an organization to be recognized with these values (Mohdali, 2013). Thus, this study investigates the influence of tax knowledge as an internal value of individual taxpayers that may affect tax compliance. As tax compliance literature has pointed out, the importance of specific knowledge on taxation in shaping the attitudes of taxpayers cannot be over emphasized (Eriksen \& Fallan, 1996; Fallan, 1999; Mustafa, 1997).

Normally, tax knowledge might shape the attitudes and as such influence the behaviour of individual taxpayers. Oktaviani, Kurnia, Sunarto and Udin (2020) argued that improving tax knowledge of taxpayers, logically, will improve their level of compliance. However, taxpayers from developing countries, including Yemen, commonly do not have adequate knowledge of tax systems and their related practices (Pertiwi, Iqbal and Baridwan, 2020). The present study is likely to be the first study investigating tax knowledge in Yemen, so the output will assess the level of tax knowledge of Yemeni taxpayers. Thus, it is expected that the results of this study would be useful to tax 
authorities not only in Yemen but also in other developing countries. Furthermore, the study also adds value to the scanty literature in this area.

\subsection{Literature Review}

\subsection{Tax Compliance Studies}

This study employed the social influence theory. This theory refers to individuals' attitudes, beliefs, knowledge, emotions and opinion (Sussman \& Gifford, 2013). Hence this theory is the most appropriate in explaining the influence of knowledge on individual's behaviour (Alabede, 2012). This attributes to the fact that the attitude of a taxpayer towards payment of tax is the function of their belief and knowledge about tax. If a taxpayer has positive knowledge about tax, he may in turn, have a positive attitude towards tax payment and will have favourable tax compliance behaviour (Bidin, Idris \& Shamsudin, 2009). In this line, Hogg and Vaughan (2005) explained that social influence theory suggests that people always are affected by their surroundings, attitudes, education and knowledge. Thus, arguably, this theory may give a logical explanation for the relationship between tax knowledge and the likely behaviour of taxpayers.

Numerous studies conducted about tax compliance focused on the classical model of tax compliance, which views the phenomenon mainly from the economic perspective (Gupta \& McGee, 2010), and to some extent the social perspectives as well (Jackson \& Milliron, 1986; Fischer, Wartick \& Mark, 1992) and legal (Klepper, Mazur \& Nagin, 1991). The reviews of Jackson and Milliron (1986) and Richardson and Sawyer (2001) are considered among some comprehensive studies on tax compliance and noncompliance. The two articles of Jackson and Milliron (1986) and Richardson and Sawyer (2001) presented the most important variables, methods, issues and theories of tax compliance (Abdul-Jabbar \& Pope, 2008). However, both studies ignored some important variables. Fischer et al. (1992) classified the determinants of tax noncompliance into four categories namely, demographic, a proxy for non-compliance opportunity, attitudinal and structural. McGee and Tyler (2006) concentrated on the ethical aspect of tax non-compliance. They conducted their study in 33 countries, from Europe, Central Asia, South America and North America, to investigate the influence of demographic factors on tax non-compliance. It was found that non-compliance is ethical if the collected taxes end up in the pockets of corrupt politicians and if the tax system is unfair. In Yemen, although tax revenue is one of the essential sources of the country's income and tax non-compliance has been largely reported, the problem has been very rarely investigated (Bin-Nashwan, Al-Hamedi, Marimuthu, \& Al_Harethi, 2020). AlTtaffi and Abdul-Jabbar (2018) argued that the problem of tax noncompliance has not been explored sufficiently in the Middle East region. This is inspite of the region's importance in the world despite the fact that the problem of tax non-compliance has been reported in the region. 


\subsection{Tax Knowledge and Tax Compliance}

Tax knowledge is defined as an understanding of tax policy implemented inside a country (Newman, Charity, \& Ongayi, 2018). Pertiwi, Iqbal \& Baridwan (2020) explained that tax knowledge is interpreted as everything that is known and understood in relation to tax law. Ahmad, Mustafa and Noor (2007) provided a simple and clear definition of tax knowledge. They explained that tax knowledge is defined as the ability of the taxpayer to understand tax laws and compute their tax liabilities. Some studies on tax compliance considered specific tax knowledge as part of the general education background of the taxpayers (Alabede, 2012). Spilker (1995) identified the types of knowledge needed in taxation to include declarative knowledge and procedural knowledge. Declarative tax knowledge is knowledge about tax facts and concepts while procedural tax knowledge is detailed knowledge about how to perform various tasks in taxation. Spilker (1995) declared that procedural knowledge might be developed through training and experience. The type of knowledge that may be easily acquired by taxpayers without much effort is declarative knowledge.

On the effect of tax knowledge on tax compliance behaviour, Adam and Webley (2012) and Palil (2010) suggested that tax knowledge is a crucial factor of tax compliance behaviour. Loo (2016) maintained that tax knowledge is the most influential factor in determining taxpayers' compliance behaviour, especially when implementing the selfassessment system. In the course of this, Kasippilai and Abdul-Jabbar (2013) reported that having sufficient tax knowledge would certainly lead to higher tax compliance rates.

The literature showed that results of empirical studies are not consistent. Particularly, Harris (2013) claimed that tax knowledge has no significant influence on taxpayers' compliance behaviour and thus knowledgeable taxpayers are not necessarily compliant. This result was confirmed by Nyamwanza, Mavhiki, Mapetere and Nyamwanza (2014) and Fauziati et al. (2016) in Zimbabwe and Indonesia respectively. Nevertheless, these studies are not consistent with other studies where it was found that the influence of tax knowledge on taxpayers' compliance behaviour is significant. Particularly, Mustafa (1997) argued that taxpayers with knowledge of tax laws are likely to comply better compared with taxpayers without such knowledge. Mckerchar and Hansford (2015) claimed that the absence of tax knowledge may lead to non-compliance either intentionally or unintentionally. In supporting these assertions, the studies of Manuputty and Sirait (2016), Masari and Suartana (2019), Oktaviani, Kurnia, Sunarto and Udin (2020) and Pertiwi, Iqbal and Baridwan (2020) confirmed that the relationship between tax knowledge and taxpayers' behaviour is significant. Alabede (2012) suggested that gaining tax knowledge is likely to improve taxpayers' compliance behaviour especially in developing countries. Therefore, the current study hypothesized that the relationship between tax knowledge and compliance behaviour of individual Yemeni taxpayers is significant. 


\subsection{Research Design and Methodology}

\subsection{Sampling and Data Collection}

The respondents of the current study are the individual taxpayers who reside in Hadhramout Governorate since this governorate is considered the most stable area of Yemen compared to other parts in view of ongoing political crisis (Bin-Nashwan, Abdul-Jabbar, Dziegielewski \& Aziz, 2020). Therefore, it is considered a safe area for citizens of all Yemeni governorates including those who were forced to abscond to Hadramout governorate to settle down and conduct their businesses. In other words, Hadhramout governorate is the largest among the governorates of Yemen in terms of area and is currently the most secure and prosperous region in the country for conducting business (Bin-Nashwan, Abdul-Jabbar, \& Romle, 2016). The population of the present study are those individual taxpayers whose main income is from doing business. Iredele (2018) suggested when complete population units is unavailable, convenience sampling technique can be used. A survey research design was employed in the present study because it is the most appropriate way to collect primary data to assess beliefs, personal and social facts and attitude. Therefore, this study employed a survey research design to gather the required data from the largest five cities in Hadhramout, namely, Mukalla, Al-Sheher, Ghail Bawazir, Seiyun and Tareem.

However, for the purpose of confirming the goodness of the measurement and to avoid any mistranslation of the words, expressions and concepts used in the development of the questions, several steps were taken in translation into Arabic version. Following the pre-test, besides language issue, the hypothetical scenario was modified slightly and order of Islamic views was rearranged. No major modification was made. However, a pilot study was performed on this final version of the questionnaire to test the reliability and to make sure that the items were properly understood. Then the final version of the questionnaire was distributed. The outcomes of the efforts made by the researchers, who distributed 350 questionnaires, yielded a total of 287 returned usable questionnaires, translating to a response rate of $82 \%$.

\subsection{Measurement of Variables}

Tax compliance, which is the dependent variable of this study, is considered to be a sensitive issue (Kirchler \& Maciejovsky, 2001); therefore, it is preferable to collect the data indirectly. Kirchler and Maciejovsky (2001) argued that the use of a scenario is the best way as it may reduce personal bias. Therefore, to measure the dependent variable of the current study, the hypothetical scenario case was adapted from the literature. Brown and Mazur (2003) acknowledged tax compliance as having four components, namely, reporting, deduction, filing and payment. To measure the compliance for each component, the respondents were required to read the hypothetical scenario and answer 
the questions. As for tax knowledge of the respondents, it is defined as the ability of the taxpayer to understand tax laws and compute tax liabilities (Ahmad et al. 2007). Many studies in Malaysia (Kasipillai, 1997; Manaf, 2004; Mustafa, 1997) measured the knowledge of taxpayers on the tax laws and concepts while Eriksen \& Fallan (1996) measured taxpayer understanding of the tax laws and computations of tax liabilities. Tax knowledge in this study was evaluated in two areas including income to be reported in tax return and expenses to be claimed. Each area was measured using three items and these items were scaled as yes (3), no (1) and do not know (2). In other words, six items were used to measure tax knowledge in this study with three items each on income to be included and expenses to be deducted in tax returns respectively [see the appendix].

\subsection{Data Analysis and Findings}

\subsection{Respondents Profile}

In the present study, the data were analysed using SPSS 24. Statistical tools include descriptive statistics, data quality tests, classic assumption tests using normality, multicollinearity and heteroscedasticity tests. The regression analysis technique used is simple regression.

Table 1

Summary of Respondents' Profiles $(n=287)$

\begin{tabular}{llrc}
\hline Demographic characteristics & Sub-characteristics & $n$ & $\%$ \\
\hline \multirow{3}{*}{ Age (years) } & Less than 30 30 & 79 & $28 \%$ \\
& $30-50$ & 106 & $37 \%$ \\
\multirow{2}{*}{ Gender } & More than 50 & 102 & $35 \%$ \\
\hline \multirow{3}{*}{ Marital status } & Male & 257 & $90 \%$ \\
& Female & 30 & $10 \%$ \\
\hline \multirow{3}{*}{ Education } & Single & 57 & $20 \%$ \\
& Married & 199 & $69 \%$ \\
\hline \multirow{2}{*}{ Sector } & Others & 31 & $11 \%$ \\
& Before secondary school & 46 & $16 \%$ \\
& Secondary school/Diploma & 144 & $50 \%$ \\
& Bachelor's degree and above & 97 & $34 \%$ \\
\hline
\end{tabular}

The demographic characteristics of the sample are presented in Table 1. As illustrated in the table, out of 287 respondents, $37 \%$ are between 30 and 50 years old and $35 \%$ are 
more than 50 years. As for gender, a large majority of respondents (90\%) were male and $69 \%$ of the respondents were married. For education, half of them gave their level of education as up to secondary school/ Diploma. Around 64\% of the respondents are working in the governmental sector.

\subsection{Descriptive Statistics of Variables}

Tax-compliance was measured using 4 situations: reporting compliance, deduction compliance, filing compliance and payment compliance. The overall tax compliance was described in three categories: fully compliant, partial compliant and fully noncompliant. The fully compliant respondents are those who are compliant in all four situations, while the fully non-compliant are those who are totally non-compliant in the four situations. The partially non-compliant are those respondents who are compliant in some situations but not compliant in some others. Table 2 illustrates the level of tax compliance and non-compliance.

Table 2

Summary of Overall Tax Compliance and Non-Compliance Behaviour

\begin{tabular}{lcccccc}
\hline & Compliant & \multicolumn{2}{c}{ Non-compliance } \\
\cline { 3 - 7 } & & & $\begin{array}{c}\text { Partially } \\
\text { compliant }\end{array}$ & \multicolumn{2}{c}{$\begin{array}{c}\text { Fully non- } \\
\text { compliant }\end{array}$} \\
\cline { 2 - 7 } & $\mathrm{N}$ & $\%$ & $\mathrm{~N}$ & $\%$ & $\mathrm{~N}$ & $\%$ \\
\hline Tax compliance and non-compliance & 92 & $32 \%$ & 65 & $23 \%$ & 130 & $45 \%$ \\
\hline
\end{tabular}

Table 2 shows three levels of compliance and non-compliance - it indicates that only $32 \%$ of the respondents were fully compliant, whereas $45 \%$ of the respondents were fully non-compliant and $23 \%$ of the respondents were partially compliant in paying their tax. Hence, it could be concluded that the level of tax non-compliance is high.

As for the descriptive statistics regarding the respondents' knowledge of tax laws, the analysis shows that the mean scores concerning the respondents' knowledge on taxable income and expenses allowed for deduction under Yemeni income tax laws range from 1.11 to 1.34 together with the standard deviation from 0.23 to 0.40 as shown in Table 3 .

For interpretation, the current study followed the $50^{\text {th }}$ percentile method proposed by the National Institute of Technology Standard USA (2010), which is defined as a statistical tool that provides an estimate of the proportion of the data that should fall above and below a particular range. Therefore, the overall result of the descriptive analysis indicates that the respondents do not have adequate knowledge of tax laws. 
Table 3

Summary of Descriptive Statistics of Tax Knowledge

\begin{tabular}{lcc}
\hline Statements & Mean & Std.D \\
\hline Interest on saving account & 1.17 & 0.26 \\
Rent received from letting out a house & 1.11 & 0.23 \\
Dividend received from a company & 1.12 & 0.27 \\
Provision for doubtful debt & 1.22 & 0.34 \\
Medical expenses & 1.32 & 0.35 \\
Loss on sale of company shares & 1.34 & 0.40 \\
\hline
\end{tabular}

\subsection{Regression Analysis}

To test the relationship between tax knowledge of the respondents and their likely tax compliance behaviour, simple regression analysis was carried out as shown in Table 4.

Table 4

Summary of regression results

\begin{tabular}{lcccc}
\hline Variables & $\beta$ & $t$ & Sig. \\
\hline Tax knowledge $\rightarrow$ Tax compliance behaviour & 0.113 & 3.117 & 0.001 \\
\hline Adjusted $R^{2}$ & 18.3 & & & \\
$f$-value & 64.77 & & & \\
$p$-value & 0.000 & & & \\
\hline
\end{tabular}

The analysis revealed that the adjusted $\mathrm{R}^{2}$ is 18.3 , which means that tax knowledge has an ability to explain $18.3 \%$ of tax compliance behaviour significantly $(\mathrm{p}<0.05$, $\mathrm{f}=64.77 ; \beta=0.113)$. This result indicates that tax compliance is improved when tax knowledge is higher. The literature shows that this result is similar to numerous previous studies such as those of Nyamwanza et al. (2014), Palil (2010), Fauziati et al. (2016), Masari and Suartana (2019) and Pertiwi et al. (2020). Finally, it could be argued that the analysis confirmed the findings of many previous studies concerning the influence of tax knowledge on the behaviour of taxpayers. Moreover, the findings are supported by the social influence theory, which suggests that people always are affected by their surroundings, attitudes, education and knowledge. Thus, the government is recommended to improve the people's tax knowledge by conducting courses, seminars and workshops. This action may lead to enhanced tax compliance and increase tax revenues which will solve several problems suffered by the government. 


\subsection{Concluding Remarks}

This study investigated the influence of tax knowledge on compliance behaviour of taxpayers and provided evidence of a strong association between taxpayers' knowledge of the tax system with their compliance behaviour. Specifically, the statistical analyses carried out in this study revealed that tax knowledge influence tax compliance behaviour positively. The regression result supported the claims made in the social influence theory, in which knowledge and education have an impact on the behaviour of people.

Theoretically, this study is likely to be the first to investigate the influence of tax knowledge in Yemen. Therefore, by focusing on Yemen as a developing country, the current study answered the call by many studies on tax compliance to bridge the gap between developing and developed countries. Practically, the study's findings are relevant to policymakers, professionals, tax authorities and researchers in Yemen and other developing countries. Particularly, the study provides significant insights into a roadmap that helps in understanding the most influential factor affecting taxpayers' behaviour in Yemen. This will certainly contribute to improving tax collection which is in line with the Yemeni government policy of enhancing the level of tax compliance. In other words, this result provides insights into the appropriate actions that should be taken by the government to encourage voluntary tax compliance. Governments are advised by the authors to improve tax knowledge of citizens which may boost the level of tax compliance.

Even though this study offers some interesting results, it has some limitations that need to be acknowledged. The focus of this study was only on one governorate in Yemen. Future research may extend this investigation to cover several governorates in the country or other Middle Eastern contexts. Since the literature showed that the results of the relationship between tax knowledge and tax compliance are inconsistent, this relationship may be moderated by certain variables. Such investigations may provide a further explanation concerning taxpayers' behaviour for a better understanding of their compliance decisions.

\section{Acknowledgments}

The authors would like to thank the editor of JBMA and the anonymous reviewers for their careful reading and constructive suggestions.

\section{References}

Abdul-Jabbar, H., \& Pope, J. (2008). Exploring the relationship between tax compliance costs and compliance issues in Malaysia. Journal of Applied Law and Policy, $1(1), 1-20$. 
Adam, C. \& Webly, P. (2012). Small business owner's attitude on vat compliance in the UK. Journal of Economy Psychology, 22(2), 195-216.

Ahmad, M. A., Mustafa, M. H., \& Noor, M. A. (2007). The effects of knowledge on tax compliance behaviour among Malaysian taxpayers. Retrieved March 14, 2020, from ibacnet.org/bai2007/proceedings papers/2007bai7357.doc.

Alabede, J. O. (2012). An investigation of factors influencing taxpayers compliance behaviour: evidence from Nigeria. Unpublished doctoral dissertation, Universiti Utara Malaysia.

Al-Saadi, M. (2014). International cooperation: Vision and mission. Al-Thawra Gazette (Issued daily by the Yemeni Prime Minister). Issue of 17 July, 2014. Sana'a.

Al-Ttaffi, L. H. A. (2017). Determinants of tax non-compliance behaviour of Yemeni SMEs: a moderating role of Islamic religious perspective. Unpublished doctoral dissertation, Universiti Utara Malaysia.

Al-Ttaffi, L. H. A., \& Abdul-Jabbar, H. (2018). Geopolitical differences and tax non-compliance among Yemeni SMEs. Journal of Business Management and Accounting, 8(1), 31-45.

Aziz, S. A., \& Al_Harethi, A. R. S. (2018). Factors Determining Tax Administration Efficiency in Hadhramout, Yemen: Perception from Individual Taxpayers. Paper presented at 5th International Conference on Accounting Studies (ICAS 2018), Penang, Malaysia, October 2018.

Baru, A. (2016). The impact of tax knowledge on tax compliance. Journal of Advanced Research in Business and Management Studies, 6(2), 22-30.

Bidin, Z., Idris, K., \& Shamsudin, F. (2009). Predicting compliance intention on zakah on employment income in Malaysia: An application reasoned action theory. Jurnal Pengurusan, 28, 85-102.

Bin-Nashwan, S. A., Abdul-Jabbar, H., \& Romle, A. R. (2016). The application of theory of planned behaviour on business zakah compliance in Yemen: A proposed framework. Middle-East Journal of Scientific Research, 24(6), 2052-2057.

Bin-Nashwan, S. A., Abdul-Jabbar, H., Dziegielewski, S. F., \& Aziz, S. A. (2020). Moderating Effect of Perceived Behavioral Control on Islamic Tax (Zakah) Compliance Behavior among Businessmen in Yemen. Journal of Social Service Research, https://doi.org/10.1080/01488376.2020.1767260.

Bin-Nashwan, S. A., Al-Hamedi, A. M., Marimuthu, M., \& Al_Harethi, A. R. (2020). Study on system fairness dimensions and tax compliance in the Middle East context. Problems and Perspectives in Management, 18(1), 181-191.

Brown, R. E., \& Mazur, M. J. (2003). IRS's comprehensive approach to compliance measurement. National Tax Association Symposium. New York: National Tax Association.

Central Organization of Control \& Audit COCA. (2016). Annual report. Retrieved from http://www.arabosai.org 
Eriksen, K., \& Fallan, L. (1996). Tax knowledge and attitudes towards taxation; A report on a quasi-experiment. Journal of Economic Psychology, 17(3), 387-402. Fallan, L. (1999). Gender, exposure to tax knowledge, and attitudes towards taxation: An experimental approach. Journal of Business Ethics, 18(2), 173-184.

Fauziati, P., Minovia, A. F., Muslim, R. Y., \& Nasrah, R. (2016). The impact of tax knowledge on tax compliance case study in Kota Padang, Indonesia. Journal of Advanced Research in Business and Management Studies, 2(1), 22-30.

Feust, C., \& Riedel, N. (2009). Tax evasion, tax avoidance and tax expenditures in developing countries: A review of the literature. Report prepared for the UK Department for International Development (DFID).

Fischer, C. M., Wartick, M., \& Mark, M. (1992). Detection probability and tax compliance: A review of the literature. Journal of Accounting Literature, 11(2), $1-46$.

Gupta, R., \& McGee, R. W. (2010). A Comparative study of New Zealanders' opinion on the ethics of tax evasion: Students versus Accountants. New Zealand Journal of Taxation Law and Policy, 16(1), 47-84.

Hanefah, M. (1997). An evaluation of Malaysian tax administrative system and taxpayers perceptions towards assessment system, tax law fairness and tax law complexity. Unpublished doctoral dissertation, Universiti Utara Malaysia.

Harris, T.D. (2013). The effect of tax knowledge on individual's perceptions of fairness and compliance with federal income tax system: An empirical study. Unpublished manuscript, University of South Carolina, South Carolina.

Hogg, M. A., \& Vaughan, G. M. (2005). Social Psychology, Fourth edition. Harlow: Pearson Education Ltd.

Iredele, O. (2018). Assessment of Voluntary Tax Compliance among Informal Economy in Nigeria. Paper presented at 89th ISERD International Conference, Oxford, United Kingdom, October 2017.

Jackson, B. R., \& Milliron, V. C. (1986). Tax compliance research: Finding, problem and prospects. Journal of Accounting Literature, 5(1), 125-165.

Kasipillai, J., \& Abdul-Jabbar, H. (2013). Gender and ethnicity differences in tax compliance. Asian Academy of Management Journal, 11(2), 73-88.

Kirchler, E., \& Maciejovsky, B. (2001). Tax compliance within the context of gain and loss situations, expected and current asset position, and profession. Journal of Economic Psychology, 22(2), 173-194.

Klepper, S., Mazur, M., \& Nagin, D. (1991). Expert intermediaries and legal compliance: The case of tax preparers. Journal of Law \& Economics, 34(1), 205-229.

Loo, E.C. (2016). The influence of the introduction on self-assessment on compliance behaviour of individual taxpayers in Malaysia, Doctoral dissertation, University of Sydney.

Manaf, N. A. (2004). Land tax administration and compliance attitude in Malaysia (Unpublished doctoral thesis). University of Nottingham, United Kingdom. 
Manuputty, I. G., \& Sirait, S. (2016). Pengaruh Pengetahuan Perpajakan dan Penerapan Self Assesment System Terhadap Kesadaran Wajib Pajak Serta Dampaknya Terhadap Kepatuhan Wajib Pajak Pada KPP Pratama Jakarta Panjaringan. Media Akuntansi Perpajakan, 1(2).

Mas'ud, A., Aliyu, A. A., Gambo, E. M. J., Al-Qudah, A. A., \& Al Sharari, N. (2014). Tax rate and tax compliance in Africa. European Journal of Accounting Auditing and Finance Research, 2(3), 22-30.

Masari, N. M. G., \& Suartana, I. W. (2019). Effect of tax knowledge, service quality, tax examination, and technology of compliance regional tax mandatory. International research journal of management, IT and social sciences, 6(5), 175-183.

McGee, R. W., \& Tyler, M. (2006). Tax evasion and ethics: A demographic study of 33 countries. Paper Presented at the Fifteenth Annual World Business Congress of the International Management Development Association (IMDA), Sarajevo, Bosnia, June 2006.

McKerchar, M. \& Hansford, A. (2015). Achieving innovation and global competitiveness through research and development tax incentives: Lessons for Australia from the UK. Australian Tax Forum, 27(1), 3-23.

Ministry of Planning \& International Cooperation MPIC. (2018). Annual Report. Retrieved from http://www.yemen.gov.ye

Mohdali, R. (2013). The Influence of Religiosity on Tax Compliance in Malaysia. Unpublished doctoral dissertation, Curtin Business School, School of Economics and Finance, Curtin University, Australia.

Mohdali, R., \& Pope, J. (2012). The effects of religiosity and external environment on voluntary tax compliance. New Zealand Journal of Taxation Law and Policy, 18(2), 119-139.

Mustafa, M. H. (1997). An evaluation of Malaysian tax administrative system and taxpayers perceptions towards assessment system, tax law fairness and tax law complexity. (Unpublished doctoral thesis), Universiti Utara Malaysia.

National Institute of Standard and Technology USA. (2010). E-handbook of statistical methods. Retrieved July 19, 2019, from www.itl.nist.gov/div898/handbook.

Newman, W., Charity, M., \& Ongayi, W. (2018). Literature review on the impact of tax knowledge on tax compliance among small medium enterprises in a developing country. International Journal of Entrepreneurship, 22(4), 1244-1259.

Nyamwanza, T., Mavhiki, S., Mapetere, D., \& Nyamwanza, L. (2014). An analysis of SMEs' attitudes and practices toward tax compliance in Zimbabwe. Sage Open, 4(3), 322-328.

Obaid, M. M., Ibrahim, I., \& Udin, N. M. (2020). An Investigation of the Determinants of Tax Compliance Among Yemeni Manufacturing SMEs Using the Fisher Model. International Journal of Psychosocial Rehabilitation, 24(04), 18091824.

Oktaviani, R., Kurnia, H., Sunarto, S., \& Udin, U. (2020). The effects of taxpayer knowledge and taxation socialization on taxpayer compliance: The role of taxpayer awareness in developing Indonesian economy. Accounting, 6(2), 89-96. 
Palil, M. R. (2010). Tax knowledge and tax compliance determinants in selfassessment system in Malaysia. Unpublished doctoral dissertation, University of Birmingham.

Pertiwi, A. R., Iqbal, S., \& Baridwan, Z. (2020). Effect of fairness and knowledge on tax compliance for Micro, Small, and Medium Enterprises (MSMEs). International Journal of Research in Business and Social Science, 9(1), 143-150.

Richardson, M., \& Sawyer, A. J. (2001). Taxonomy of the tax compliance literature: Further findings, problems and prospects. Australian Tax Forum, 16(2), $137-$ 284.

Ross, A. M., \& McGee, R. W. (2012). Education level and ethical attitude toward tax evasion: A six-country study. Journal of Legal, Ethical and Regulatory Issues, 15(2), 93-138.

Spilker, B. C. (1995). The effects of time pressure and knowledge on key word selection behaviour in tax research. The Accounting Review, 70(1), 49-70.

Sussman, R., \& Gifford, R. (2013). Be the change you want to see: Modeling food composting in public places. Environment and Behavior, 45(3), 323-343.

Transparency International's Quarterly Newsletter TIQN. (2005). Auditing body to fight corruption. Retrieved from http://www.transparency.org/content/ download/2270/14250/version/1/file/ti_q_jun2005.pdf

United Nations Development Program UNDP. (2005). Program on /Governance in the Arab Region. Washington District of Colombia.

Umar M.A, Derashid C, Ibrahim I. (2017). What Is Wrong With the Fiscal Social Contract of Taxation in Developing Countries? A Dialogue With Self-Employed Business Owners in Nigeria. SAGE Open, 7(4), 1 - 10. doi:10.1177/2158244017745114

Wentworth, D. K., \& Rickel, A. U. (1985). Determinants of tax evasion and compliance. Behavioral Sciences \& the Law, 3(4), 455-466. 


\section{Appendix \\ Items and measurements of variables}

\section{Tax compliance:}

Read the following scenario and kindly indicate your opinion (by way of a circle): Suppose that the annual sales income of Ahmed's enterprise amounted YR130.000, and the total operating expenses amounted YR30.000. The amount which has to be reported for tax purpose is YR100.000. However, Ahmed is almost certain that the tax office will not audit him and would not know if $40 \%$ of the taxable income was not reported.

Additionally, he paid YR10.000 to repair his personal car. In preparing the tax return, he is thinking about claiming the costs of repair as if the car was used in his business. Legally, such a claim is not allowable, but he is almost certain that he will not be audited and that the tax authority would not be able to detect the deduction.

The income Tax Law provides that tax return has to be filed with tax authority within 120 days from commencement of year (January) of assessment, and tax should be paid within 60 days from the date of assessment notice.

1) Indicate the taxable income that Ahmed should include in his report:
(a) YR100.000
(b) YR60.000

(c) Other amount, please specify

2) How much should Ahmed deduct as business expenditure?
(a) YR 30.000
(b) 40.000
(c) Other amount, please specify

3) Which of the dates below should Ahmed file his income tax?
(a) On 30th April or before
(b) After 30th April
(c) Other date, please specify

4) How many days after receiving assessment notice should Ahmed pay his income tax:
(a) 60 days or less
(b) More than 60 days
(c) Other, please specify 


\section{Tax knowledge}

- $\quad$ Are the following income taxable under Yemeni income tax law?:

\begin{tabular}{|c|c|c|c|}
\hline \multicolumn{1}{|c|}{ Statement } & Yes & No & $\begin{array}{c}\text { Do not } \\
\text { know }\end{array}$ \\
\hline 1) Interest on saving account & & & \\
\hline 2) Rent received from letting out a house & & & \\
\hline 3) Dividend received from a company & & & \\
\hline
\end{tabular}

- Are the following business/personal expenses allowed for deduction under Yemeni income tax law?:

\begin{tabular}{|c|c|c|c|}
\hline \multicolumn{1}{|c|}{ Statement } & Yes & No & $\begin{array}{c}\text { Do not } \\
\text { know }\end{array}$ \\
\hline 1) Provision for doubtful debt & & & \\
\hline 2) Medical expenses & & & \\
\hline 3) Loss on sale of company shares & & & \\
\hline
\end{tabular}

nts' Profiles $(n=287)$ 